\title{
Wastewater Reuse in Kuwait and Its Impact on Amounts of Pollutants Discharged into the Sea
}

\section{B Al-Anzi ${ }^{1}$, A Abusam ${ }^{2 *}$ and A Shahalam ${ }^{2}$}

${ }^{1}$ Environmental Technology Department and Management, College for Women, Kuwait University, P.O. Box 5969 Safat, Kuwait ${ }^{2}$ Kuwait Institute for Scientific Research, Water Resources Division, Water Technologies Department, P.O. Box 24885 Safat 13109, Kuwait

\begin{abstract}
Kuwait has recently implemented a vigorous campaign that aims to reclaim and reuse all treated wastewater. This paper presents the present status of wastewater treatment, reclamation and reuse in Kuwait, and discusses the impact of wastewater reuse on the amounts of pollutants discharged into the sea. Analysis of the historical records of the wastewater treatment plants has indicated that the reuse of reclaimed wastewater in Kuwait has greatly reduced the amounts of pollutants discharged into the sea, from about $65 \%$ of treated wastewater in year 2000 to less than $30 \%$ in year 2010. However, the amounts of treated wastewater discharged into the sea were predicted to start increasing again by the year 2020, especially if the future plans of the Ministry of Public Works (MPW) will not be implemented by that time.
\end{abstract}

\section{Introduction}

Kuwait is situated in a severe arid environment, and its freshwater resource is limited to scare amounts of brackish groundwater. Kuwait mainly depends on desalination of sea water to satisfy its fresh water demands. However, Kuwait has recently established wastewater reclamation plans that aim to augment its water resources by adding a new source of treated effluents. The prime goal of these plans is to utilize $100 \%$ of the reclaimed municipal wastewater mainly in restricted agricultural irrigation (e.g. fodder crops irrigation), greenery landscaping (grass, plants, trees and bushes) and in the development of a forestation areas [1].

Reuse of wastewater for irrigation purposes has proved to be one of the best ways to recycle nutrients and water and thus protect the environment and the public health [2]. It contributes directly to the environmental sustainability by increasing crop production and decreasing amounts of pollutants discharged into the environment.

This main aims of this paper are (i) to present and assess the status of wastewater treatment, reclamation and reuse in Kuwait, and (ii) to discuss the impact of wastewater reuse on the amounts of pollutants discharged into the sea.

\section{Municipal Wastewater Treatment and Reuse in Kuwait}

\section{Main municipal wastewater treatment plants in kuwait}

Table 1 present's information about the construction year, treatment level and design capacity of the four main municipal wastewater treatment plants in Kuwait (Jahra, Riqqa, Um-AlHaiman and Sulaiybia). Presently, Kuwait generates about 600,000 $\mathrm{m}^{3} / \mathrm{d}$ of wastewater. About $60 \%$ of this amount $\left(375 \mathrm{~m}^{3} / \mathrm{d}\right)$ is treated to an advance level, of ultra filtration (UF) and reverse osmosis (RO) membrane filtration, at Sulaibiya plant which is the world's largest membrane-based water reclamation facility. The rest of the generated wastewater $(40 \%)$ is treated up to the tertiary level (rapid sand filtration and chlorination) utilizing other three conventional activated sludge plants. More details about the treatment systems used in the main wastewater treatment plants in Kuwait are given in Table 2.

As shown in Table 3, the raw wastewater treated at Kuwait municipal plants is basically a domestic wastewater that can be classified as a medium strength wastewater [3]. However, the high concentration of phosphorus contents of the raw wastewater is probably due to illegal discharges of industrial wastewaters into public sewers. Illegal discharges of industrial wastewaters into public sewers are believed to be practiced in Kuwait for a long time [4].

\section{Present status of wastewater reuse in kuwait}

At present, the reuse of wastewater in Kuwait is limited mainly

\begin{tabular}{|l|l|l|l|}
\hline Plant & Construction Year & Treatment Level & $\begin{array}{l}\text { Design Capacity } \\
\text { (m3/day) }\end{array}$ \\
\hline Jahra & 1981 & Teriary & 86,000 \\
\hline Riqqa & 1982 & Teriary & 180,000 \\
\hline Sulaibiya & 2005 & Advanced & 375,000 \\
\hline Um Alhaiman & 2001 & Teriary & 20,000 \\
\hline
\end{tabular}

Table 1: Basic Information about Kuwait Main Municipal Wastewater Treatment.

\begin{tabular}{|l|l|l|l|}
\hline Plant & Secondary Treatment & $\begin{array}{l}\text { Tertiary } \\
\text { Treatment }\end{array}$ & $\begin{array}{l}\text { Advanced } \\
\text { Treatment }\end{array}$ \\
\hline Jahra & $\begin{array}{l}\text { 6 Conventional activated-sludge } \\
\text { systems operated in extended } \\
\text { aeration mode }\end{array}$ & $\begin{array}{l}\text { Sand filtration+ } \\
\text { chlorination }\end{array}$ & --- \\
\hline Riqqa & $\begin{array}{l}\text { 12 Conventional Activated-sludge } \\
\text { systems operated in extended } \\
\text { aeration mode }\end{array}$ & $\begin{array}{l}\text { Sand filtration+ } \\
\text { chlorination }\end{array}$ & --- \\
\hline Sulaibiya & 9 BNR activated-sludge systems & --- & $\begin{array}{l}\text { Disc filtration } \\
+ \text { UF+RO+ } \\
\text { chlorination }\end{array}$ \\
\hline $\begin{array}{l}\text { Umm-Al- } \\
\text { Haiman }\end{array}$ & 4 Oxidation ditch systems & $\begin{array}{l}\text { Sand filtration } \\
+U V+ \\
\text { chlorination }\end{array}$ & --- \\
\hline
\end{tabular}

Table 2: Treatment Systems Used in Kuwait Main Municipal Wastewater Treatment Plants (MPW, 2006).

*Corresponding author: A Abusam, Kuwait Institute for Scientific Research Water Resources Division, Water Technologies Department, P.O. Box 24885 Safat 13109, Kuwait, Tel: +965-4672223; E-mail: aabusam@kisr.edu.kw

Received December 01, 2011; Accepted May 24, 2012; Published May 26, 2012

Citation: Al-Anzi B, Abusam A, Shahalam A (2012) Wastewater Reuse in Kuwait and Its Impact on Amounts of Pollutants Discharged into the Sea. J Environ Anal Toxicol S3:003. doi:10.4172/2161-0525.S3-003

Copyright: $\odot 2012$ Al-Anzi B, et al. This is an open-access article distributed unde the terms of the Creative Commons Attribution License, which permits unrestricted use, distribution, and reproduction in any medium, provided the original author and source are credited. 


\begin{tabular}{|l|l|l|l|l|}
\hline Plant & COD $(\mathbf{m g} / \mathbf{l})$ & $\mathbf{T S S}(\mathbf{m g} / \mathbf{l})$ & $\mathbf{N H}_{\mathbf{4}}-\mathbf{N}(\mathbf{m g} / \mathbf{l})$ & $\mathbf{T P}(\mathbf{m g} / \mathbf{l})$ \\
\hline Jahra & 243 & 180 & 27 & 23 \\
\hline Riqqa & 393 & 357 & 30 & 21 \\
\hline Sulaibiya & 492 & 227 & 32 & 30 \\
\hline Um Alhaiman & 436 & 243 & 24 & 23 \\
\hline
\end{tabular}

Table 3: Average Influent Concentrations at Kuwait Main Municipal Plants in 2005 (MPW, 2006)

to agricultural and landscaping irrigations. Other reuse applications, such as urban (e.g., toilet flushing, vehicle washing and fire protection), industrial (e.g. cooling water, boiler feed and process water) and environmental (e.g., gulf courses, hunting and equestrian clubs) are not widely practiced in Kuwait. Furthermore, artificial groundwater recharge is still limited to experimental studies. Nonetheless, interests have been shown for urban uses of treated wastewater effluent (TWE). For example, Al-Ghusain and Terro[5] has studied the suitability of TWE produced in Kuwait for reuse in concrete mixing. They have concluded that Kuwait's tertiary TWE is quite suitable for reuse in concrete mixing. Also there are interests in the reuse of grey water in Kuwait [6].

In fact, reuse of TWE in Kuwait has not just started recently. It is actually dated back to 1956, when the reuse of TWE was officially implemented at experimental farms [7]. Since then, the rate of TWE reuse in Kuwait is steadily increasing. Nowadays, reuse of TWE for irrigating only fodder crops and landscaping consumes more than $50 \%$ of the TWE produced daily [8]. Demands for TWE, however, are also steadily increasing. The Ministry of Electricity and Water (MEW) is requesting TWE for injection into the brackish aquifers. Further, Kuwait Oil Company (KOC) is asking RO brine water for oil explorations. Similarly, many factories (e.g. concrete mixing factories) are requesting TWE for reuse in various industrial operations [9].

\section{Kuwait wastewater reuse systems}

Produced TWE in Kuwait is conveyed from the wastewater treatment plants to reuse places through distribution networks or tanker truck deliveries. Actually, there are two distribution networks for TWE in Kuwait: Ministry of Public Works (MPW) distribution network and Public Authority for Agricultural Affairs and Fish Resources (PAAF) distribution network. Both MPW and PAAF distribution networks consist of pump stations, gravity mains, and pressure mains. MPW distribution network links Jahra, Riqqa and Sulaibiya WWTPs to the storage reservoirs at the Data Monitoring Centre (DMC) in Sulaibiya area. From DMC, TWE is distributed further to the main farming areas of Sulaibiya, Abdali and Wafra areas. PAAF distribution network conveys TWE from Riqqa plant to greenery areas, projects A, B1, B2 and B3 (Figure 1). Other areas such as Fintas remote area receive form Jahra, Umm-Al-Haiman and Riqqa wastewater treatment plants.

At the DMC facility, TWE is stored and chlorinated further before being distributed to points of utilizations. The DMC facility is located about $30 \mathrm{~km}$ from the center of Kuwait City. It has six effluent storage reservoirs (ESRs), pump houses, chlorination units, a laboratory for water analysis and a computerized data management facility for daily quantity and quality records of reservoir inflow and outflow. The total storage capacity of the six ESRs is $38000 \mathrm{~m}^{3}$ [10]. However, MPW is now increasing the total storage capacity to $680,000 \mathrm{~m}^{3} / \mathrm{d}$ through building new reservoirs [9].

ESRs are usually used not only for storing the TWE, but also for regulating the TWE flow rate and improving its quality. Properly designed and operated ESRs have proved to achieve these desired objectives [11]. Through regulation of TWE flow rates according to reuse demands, ESRs help in the cultivation of large area of land and in producing high crop yields [12]. Furthermore, ESRs also reduce evaporative losses and subsequent increase in soil salinity [2]. Kuwait's, DMC depends mainly on chlorination to improve the bacteriological quality of the stored water.

\section{Materials and Methods}

Pollution loads were calculated only for TWE, reused in agriculture and landscape irrigations. They were calculated as $\mathrm{kg} / \mathrm{d}$ of total solid loads (TSS), five biological oxygen demand loads $\left(\mathrm{BOD}_{5}\right)$, total nitrogen loads (TN) and total phosphorus loads (TP), through multiplying TWE average yearly volumetric flow rates by pollutants concentrations.

Pollutant loads were calculated using the records of the main municipal wastewater treatment plants (Jahra, Riqqa, Sulaibiya and Um- Haiman plants) for the years 2000, 2005, 2010, and $2020[7,13]$ Pollution loads for the year 2000 were considered to be the baseline to which the pollution loads in year 2005 and in future (year 2020) can be compared and assessed.

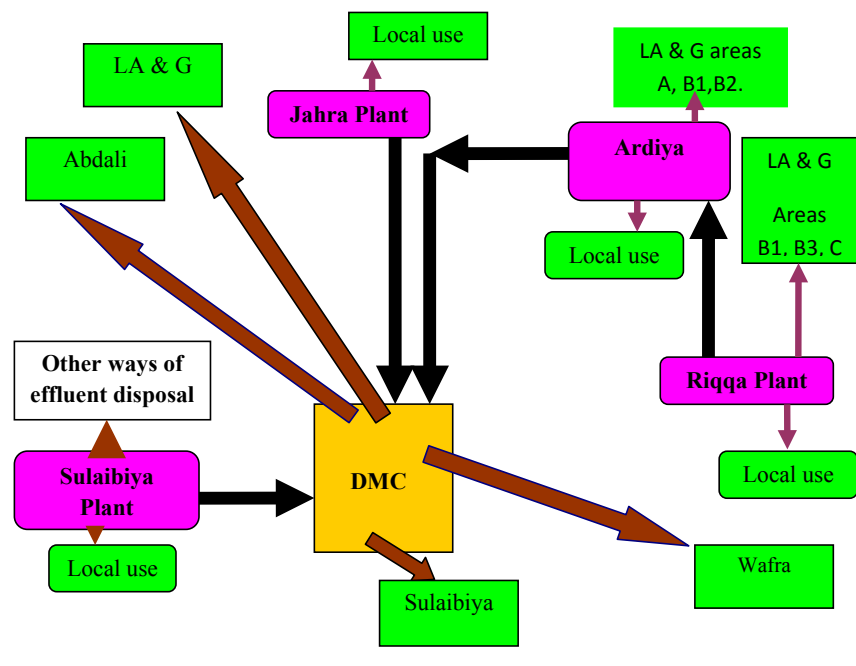

Note:

LA \& $\mathbf{G}=$ Landscaping and Greenery

Figure 1: System of Wastewater Collection and Reuse System in Kuwait (Shahalam, 2008)

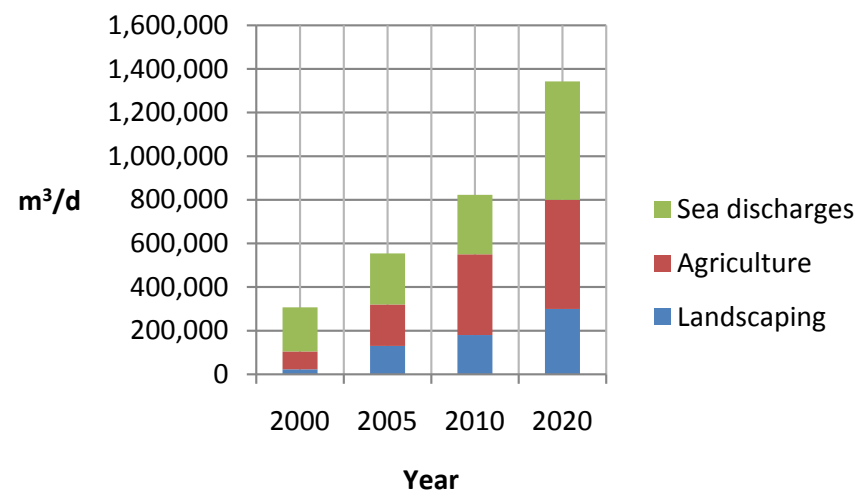

Figure 2: Volume of TWE Reused in Agriculture, Landscaping or Discharged into the Sea. 
In fact, potential pollution loads expected for the year 2020 were estimated using volumes of TWE as predicted by Shahalam et al. [8] and pollutants concentration of 2005 which were assumed to be the same for year 2020 .

Exact amounts of TWE discharged into the sea from wastewater treatment plants were actually not available for all year. For Kuwait, however, TWE not utilized as an irrigant is usually discharged into the sea. Reuse applications of TWE other than agriculture are very limited and negligible [8]. Thus, pollution loads of TWE utilized as irrigation water reflects directly the impacts of wastewater reuse in Kuwait on pollutants discharges into the sea.

\section{Results and Discussion}

Average amounts of TWE reused in Kuwait in agriculture and landscaping and that discharged into the sea are depicted Figure 2 which shows that the total amounts of TWE utilized for irrigation purposes in both agriculture and landscaping is increasing steadily with time. From the same Figure 1, one can also see that the amounts of TWE reused in agriculture and landscaping in year 2005 have increased to more than two-fold of that in year 2000. For year 2020, the rates of TWE utilization are expected to increase even further. With respect to TWE discharged into the sea, however, the same figure shows that the discharges remain the same from years 2000, 2005 and 2020. But taking into consideration the total TWE daily produced, which is increasing over the years, the rate of TWE discharged into the sea had actually been reduced, by about half, from about $65 \%$ in year 2000 to about $30 \%$ in year 2010 (Figure 2). Figure 3 was generated to show this effect. As depicted in Figure 3, percentage of TWE discharged into the sea is expected to increase from about $30 \%$ in year 2010 to about $40 \%$ in year 2020. This can be attributed to the fact that very high amounts of TWE are expected to be produced by year 2020. As reported by Shahalam et al. [8], about 0.5 million of cubic meter of TWE in excess of present storage capacity is expected to be produced in 2020. Another reason is also the limitation of TWE reuse to basically agricultural and landscape irrigations. However, amounts of TWE discharged to sea will be zero with the completion of the on-going works and plans of the MPW. The MPW is actually doubling the available TWE storage capacity and diversifying the TWE reuse applications to include industrial applications, such as reuse of TWE in concrete mixing processes and RO-brine for oil exploration [9].

With respect to reuse as irrigant, the qualities of TWE produced during both 2000 (Figure 3) and 2005 (Figure 4) were in compliance with the standards proposed for Kuwait (Tables 4). However, it should be noticed that effluents of Sulaibiya plant (Figure 4) were almost deprived of nutrients $(\mathrm{N}, \mathrm{P})$ essential for plants growth. Sulaibiya plant treats wastewater to advanced levels using UF and RO systems. The RO system is known to remove almost completely all the pollutants in wastewater. This makes Sulaibiya effluents unsuitable for reuse as irrigant. However, MPW is presently coordinating with KOC the reuse of $\mathrm{RO}$ brine in oil explorations [9].

Depending on the quality, continuous discharge of any type of wastewater into the sea can lead to many environmental and public health problems. These problems will be due to mainly excessive depletion of oxygen (high biological oxygen demand, BOD), autrophication (large amounts of $\mathrm{N}$ and $\mathrm{P}$ ), presence of pathogenic microorganisms and presence of toxic chemicals (e.g heavy metals and toxic organic compounds). Thus, Figure 4 and Figure 5 show that discharges from Jahra, Riqqa and Ardiya plants pose a serious threat to marine environment. These figures show that ammonia concentration of Jahra effluents was always greater than the proposed standard of $3 \mathrm{mg} / \mathrm{l}$. Similarly, $\mathrm{PO}_{4}$ of both Ardiya and Riqqa discharges were significantly greater than the proposed standard of $8.8 \mathrm{mg} / \mathrm{l}(2$ $\mathrm{mg} / \mathrm{l}$ as phosphorus). Usually, $\mathrm{P}$ is considered as an indicator of illegal discharges of industrial wastewater into public sewers, which seems to be a common practice in Kuwait [4].

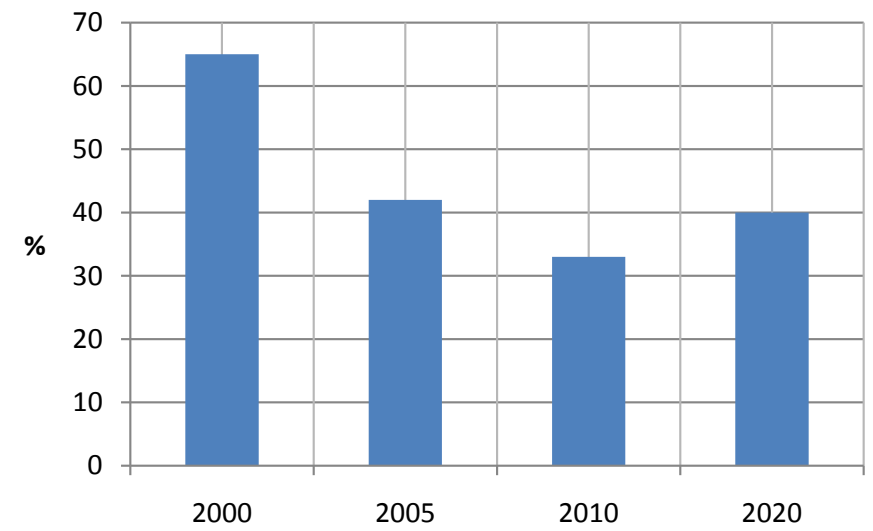

Figure 3: Percent of TWE Discharged to the Sea.

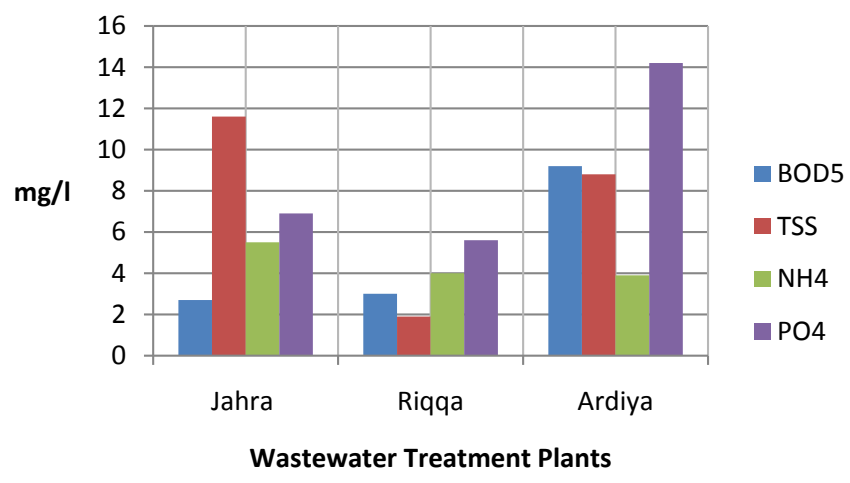

Figure 4: Average Tertiary Effluents Qualities in 2000.

\begin{tabular}{|l|l|l|l|l|}
\hline Pollutants & $\mathbf{B O D}_{\mathbf{5}}$ & $\mathbf{T S S}$ & $\mathbf{N H}_{\mathbf{4}}$ & $\mathbf{P O}_{\mathbf{4}}$ \\
\hline Standards for sea discharge & 30 & 10 & 3 & 8.8 \\
\hline Standards for reuse as irrigation water & 20 & 15 & 15 & 130 \\
\hline
\end{tabular}

Table 4: Proposed Standards (mg/l) for Treated Wastewaters Discharged into the sea and That Reused as Irriagation Water in Kuwait (Parsons, 2001).

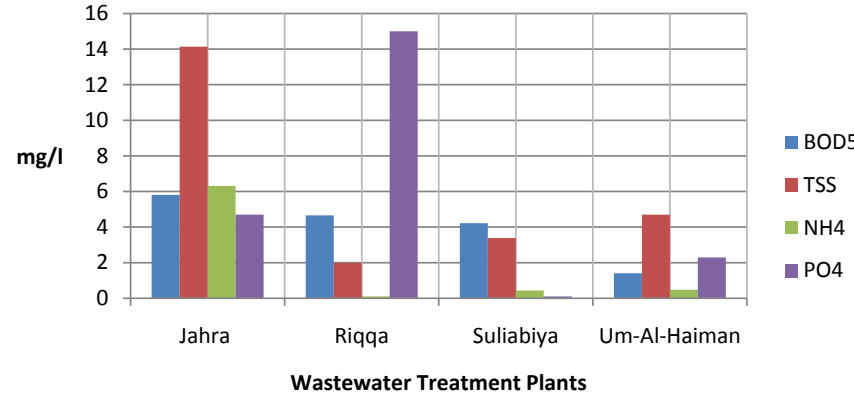

Figure 5: Average Tertiary and Advanced Effluents Qualities in 2005. 


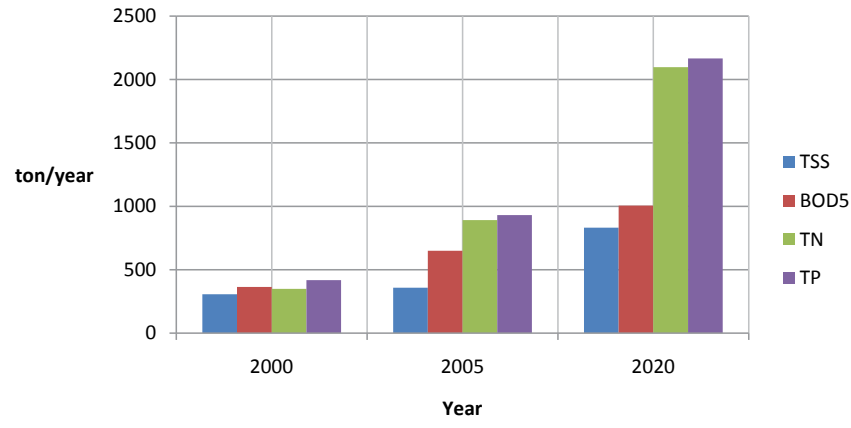

Figure 6: Amounts of Pollutants Utilized in Agriculture and Landscaping.

In short, reuse of TWE for irrigation purposes in Kuwait has resulted in utilizing large amounts of pollutants that would have been definitely ended into the sea. Figure 6 presents the amounts of pollutants that have been reused or will be reused in agriculture and landscaping during the years 2000, 2005 and 2020. It shows that the amounts of pollutants that have been or will be beneficially utilized are steadily increasing in Kuwait. As can be seen from this figure, the utilization rates, namely of nutrients (TN and $\mathrm{TP}$ ), are growing very rapidly. In fact, the rates have been doubled in comparison to that of year 2000 .

\section{Conclusions}

- Reuse of reclaimed wastewater in Kuwait has greatly reduced the amounts of pollutants discharged into the sea.

- Volumes of wastewater discharged into the sea have been drastically reduced from about $65 \%$ in year 2000 to about $30 \%$ in year 2010.

- Volumes of wastewater discharged into the sea are predicted, however, to start to increase again by 2020 . The main reasons for that are inadequate storage capacity for reclaimed wastewater and the limitation of the TWE reuse applications to basically agricultural and landscape irrigations. Completion of Ministry of Public Works (MPW) on-going activities, however, will stop completely the discharge of TWE into the sea.

\section{Acknowledgements}

Data used in this study were collected during the execution of a project entitled "Present and Future Wastewater Quantities and Reuse Demand in Kuwait (WT007C)" at KISR. This project was partially financed by the Kuwait Foundation for the Advancement of Sciences.

\section{References}

1. Razzaque MA (1995) Master plan for development of Kuwait's agricultural sector (1995-2005), Kuwait Institute for Scientific Research, Kuwait.

2. WHO (2006) Guidelines for the safe use of wastewater, excreta and greywater, Volume 2: Wastewater use in agriculture, World Health Organization, France.

3. MetCalf, Eddy, George T (1979) Wastewater Engineering: Treatment Disposal Reuse. (3rdedn), McGraw-Hill Publishing Company Ltd, New York, USA.

4. Ghobrial F, Lionel M, Patel B, Awad A (1987) Assessment of raw sewage and treated effluents characteristics in Kuwait, Kuwait Institute for Scientific Research, Kuwait.

5. Al-Ghusain I, Terro JM (2003) Use of treated wastewater for concrete mixing in Kuwait. Kuwait J Sci Eng 30: 213-228.

6. Abusam A (2008) Reuse of greywater in Kuwait. Int J Environ Stud 65:103-108

7. Parsons (2001) Parsons Engineering Science Inc. and Gulf Consult-2002 Kuwait Sanitary Master Plan, Kuwait.

8. Shahalam, A, Al-Shammari A, Abusam S, Al-Naser H (2008) Present and future wastewater quantities and reuse demand in Kuwait, Kuwait Institute for Scientific Research, Kuwait.

9. MPW (2011) Wastewater Reuse Plans.

10. Al-rashidi H, Shahalam AM, Alam S (2005) Centralized management of treated wastewater reuse in Kuwait: collection, storage and distribution, Proceedings of the $7^{\text {th }}$ Gulf Water Conference, Kuwait.

11. Mancini G, Barone C, Roccaro P, Vagliasindi FG (2007) The beneficial effects of storage on the quality of wastewater for irrigation: a case study in Sicily. Water Sci Techno 55: 417-424.

12. Barbagallo S, Cirelli GL, Consoli S, Somma F (2003) Wastewater quality improvement through storage: a case study in Sicily. Water Sci Techno 47 169-176

13. MPW (2006) Treatment Plant Data (Personal Communication, MPW staff).
This article was originally published in a special issue, Environmental Pollutants handled by Editor(s). Dr. Ben-Zhan (Benny) Zhu, China; Dr. Aijie Wang, China 